\title{
右肺上葉切除後の中葉 “不完全”捻転症に対し捻転解除術を行った一例
}

\author{
前田 光喜*1, 酒瀬川浩一 ${ }^{* 2}$, 西島 浩雄 ${ }^{* 3}$ \\ 今村 信宏*1, 森園翔一郎*1, 佐藤 雅美*1
}

\begin{abstract}
要 旨
(はじめに)肺切除後の稀な合併症として残存肺の捻転症があり，適切な診断と早期の治療介入が必要である。 また，捻転 解除術もしくは肺切除術の選択については慎重な判断を要する. (症例) 63 歳男性. 既往歴に肺気腫があり，1秒量 $1.32 \mathrm{~L}, \%$ DLCO 30.9\% と低肺機能であった. 右上葉肺癌 T2aN0M0 c-stage IB の術前診断で右上葉切除 ND2a-1 を行った. 術後 2 日目 に右肺中葉の捻転症が疑われ緊急手術を行った. 手術所見では肺壊死の所見は無く, 低肺機能を考慮し捻転解除術を行った. 術後経過は良好で自宅退院となった. (結語) 症例次第であるが, 右上葉切除後の中葉捻転に対して捻転解除術は治療選択肢 となりうる。
\end{abstract}

索引用語 : 肺捻転症, 術後合併症

lung torsion, postoperative complication

\section{はじめに}

肺切除後の稀な合併症として残存肺の捻転があり, 適 切な診断と早期の治療介入が必要である。また, 捻転し た肺の捻転解除を行うか, 肺切除まで踏み切るかについ ては慎重な判断を要する. 右上葉切除後に捻転解除術を 行った症例を経験したため報告する.

\section{症例}

症 例 : 63 歳, 男性.

主 訴：無し。

既往歴 : 肺気腫, 高血圧症, 虫垂炎術後.

喫煙歴：20本/日 $\times 38$ 年間.

現病歴: 高血圧で通院中のかかりつけ医院で, 胸部異 常院影を指摘された．前医に紹介され精查された結果, 右上葉肺癌が疑われ手術目的に当科紹介受診となった。

\footnotetext{
*1鹿児島大学大学院医歯学総合研究科呼吸器外科学分野

*2鹿児島市立病院呼吸器外科

*3鹿児島厚生連病院呼吸器外科

原稿受付 2019年 1 月 7 日

原稿採択２019年 6 月29日

本論文の要旨は第 79 回日本臨床外科学会総会で発表した.
}

胸部 X 線および CT 検査：胸部 X 線で右上肺野に 30 $\mathrm{mm}$ の境界不明膫な結節影あり. 胸部造影 $\mathrm{CT}$ 検査では, 右 $\mathrm{S} 1 / \mathrm{S} 2$ に $36 \times 30 \mathrm{~mm}$ の腫瘤を認めた。気腫肺により 右肺上葉は比較的大きく, CT volumetryでは右上葉 $1237 \mathrm{ml}(25.3 \%)$, 右中葉 $228 \mathrm{ml}(4.7 \%)$, 右下葉 1024 ml (20.9\%) であった (Fig. 1-a). COPD 病気分類 III 期のため, 術前に禁煙指導と吸入治療が導入された.

FDG-PET/CT 検査: 右上葉の原発巣にSUV max 8.3, 2 時間值 10.5 の異常集積があった.リンパ節転移や 遠隔転移を示唆する異常集積は無かった.

呼吸機能検査：VC 3.13 L，\%VC 79.5\%, FEV1.0 1.32 L, FEV1\%-G 41.37\%, \%DLCO 30.9\%, 右上葉切除後 : FEV1.0 $986 \mathrm{ml}\left(632 \mathrm{ml} / \mathrm{m}^{2}\right)$, \%FEV1.0 31.15\%, \%DLCO $30.9 \%$.

階段昇降テスト：安静時脈拍数 63/分, $\mathrm{SpO}_{2} 95 \%, 4$ 階到達時, 脈拍数 130 /分, $\mathrm{SpO}_{2} 83 \%$ まで低下したため中 止された。

手術所見 : 右上葉肺癌疑い T2aNOM0 c-stage IB の術 前診断で手術となった．右第 5 肋間の後側方開胸で手術 開始. 胸腔内に播種は認めず, 胸壁浸潤や癒着も無かっ た. 右肺上葉切除後, ND2a-1 リンパ節郭清を行った. 残 存肺の膨張を期待し肺䩲帯は切離した. air leak test は問 

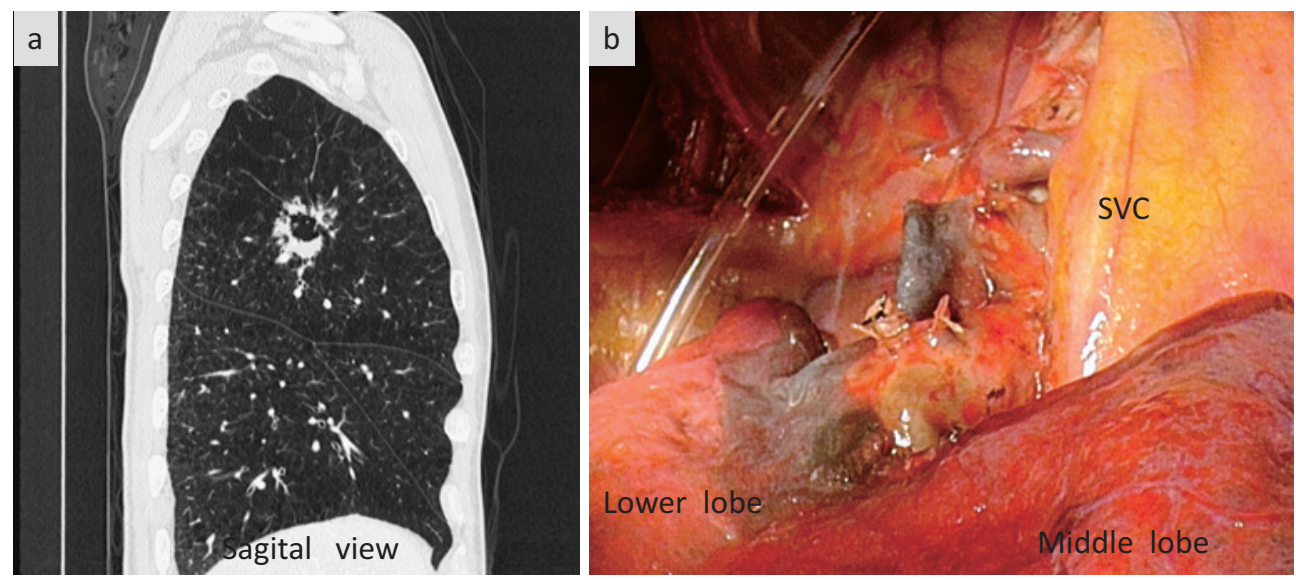

Fig. 1 (a) CT shows a lung tumor in the right upper lobe. Over-expansion of the right upper lobe reflects an emphysematous change. (b) An intraoperative image shows appropriate positioning of the residual lobe after a right upper lobectomy. SVC: superior vena cava.

題なく，残存肺が正しく伸展することを確認し閉胸した (Fig. 1-b).

術後経過：術後 1 日目の胸部 X 線で右上肺野の浸潤 影があり，中葉の無気肺が疑われた（Fig. 2-a, b)。呼吸 困難や血痰などの臨床症状や vital の異常は認められず 経過観察された. 術後 2 日目の胸部 X 線においても右中 葉無気肺を疑わせる所見であった，そのため気管支鏡検 查を行ったが，右中葉の粘膜に異常所見は無く吸引しう る喀痰は認めなかった。 また, 明らかな中葉気管支の狭 窄所見は指摘できなかった，胸部単純 CT を行ったとこ ろ右中葉の完全無気肺があり中葉捻転症が否定できず検 索目的で再手術の方針とした（Fig. 2-c，d）.

再手術所見：右肺中葉は肺門方向からみて時計回りに

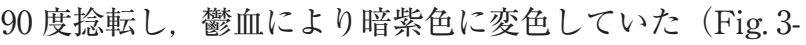
a). 明らかな壊死所見は認めず不完全な中葉捻転症と判 断し,メチルプレドニゾロン $125 \mathrm{mg}$ 静注後に捻転解除 を行った，中下葉間は完全分葉であり，右肺中葉は容易 に捻転しうると判断された。 そのため中葉固定術も行っ た。右中下葉に軽度送気を行い, Major fissure において 中下葉間をネオベール ${ }^{\circledR}$ TUBE type を併用した ENDOPATH ${ }^{\circledR}$ ETS Articulating Linear Cutter ( No Knife）で縫合固定した（Fig. 3-b）.

再手術後経過：術後は咳嗽時に軽度の air leakを認め たが，死脘に伴うものと判断された，術後 6 日にドレー ンクランプテストを開始し, 術後 7 日目にドレーンを抜 去した，安静時の酸素投与は不要であったが，歩行時に $\mathrm{SpO}_{2} 90 \%$ 以下となるため在宅酸素療法を導入する方針
となった，経過良好であったが一人暮らしであることも 考慮し地域包括ケア病棟に転棟後, 術後呼吸器リハビリ を行った，再手術後 25 日目に自宅退院された。

呼吸機能検査（再手術後 15 日目）：VC $3.26 \mathrm{~L} ％ \mathrm{VC}$ 2.22\%，FEV1.0 1.55 L，FEV1\%-G 69.85\%，\%DLCO 測定 無し.

6 分間歩行試験（再手術後 13 日目）：開始前 $\mathrm{SpO}_{2}$ $92.7 \%$, 酸素投与無しでは $\mathrm{SpO}_{2} 83 \%$ に低下し $120 \mathrm{~m}$ 歩 行, 2 分 30 秒の時点で中止した。経鼻酸素投与下 $\left(\mathrm{O}_{2}\right.$ $1 \mathrm{~L}$ で開始, $150 \mathrm{~m}$ 時点で $2 \mathrm{~L}, 240 \mathrm{~m}$ 時点で $3 \mathrm{~L}$ )では 300 $\mathrm{m}$ 歩行し, 歩行中 $\mathrm{SpO}_{2}$ 最小值 $87 \%$, 脈拍数最大值 198 bpmであった.

\section{考察}

肺捻転症は肺切除後に 0.089 ～ $0.3 \%$ の頻度で発症する とされる稀な合併症である.残存肺が 90 度以上捻転する と, 肺実質内は急速に枹血性の壊死となりうる ${ }^{1)}$. (1)無気 肺, (2)長く周囲組織と連続性のない気管支血管茎の存在, (3)葉間の完全分葉，(4)気胸拈よび胸水の存在，(5)肺䩲帯 の切離，が肺捻転症のリスク因子と言われる21.

Banki らが示した診断治療のアルゴリズムによると, $\mathrm{CT}$ と気管支鏡検查が診断の一助となる ${ }^{3)}$. 気管支鏡検査 により, 気管支の捻転や狭窄所見に加え, 出血性梗塞を 示唆する血痰の吸引や血流不良を反映した粘膜所見など が観察される。しかし，本症例では中葉気管支は容易に 通過可能であり，粘膜所見を含め捻転を強く示唆する所 見は無かった，過去の報告でも，狭窄部位の末梢気管支 

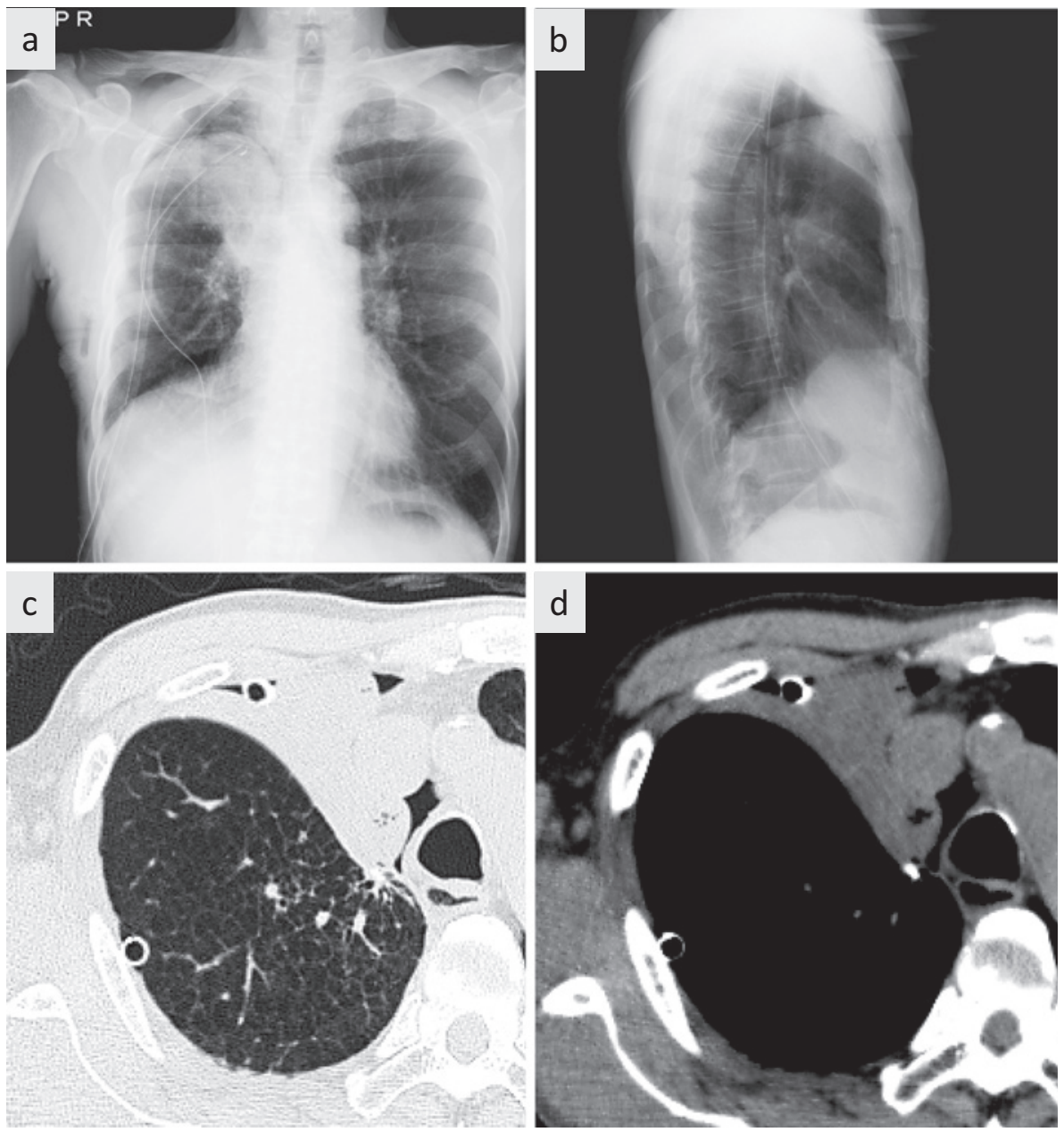

Fig. 2 (a) (b) A radiograph on postoperative day 1 showed typical opacity in the right upper lung field. (c) (d) The right middle lobe showed atelectasis based on CT on postoperative day 2 .
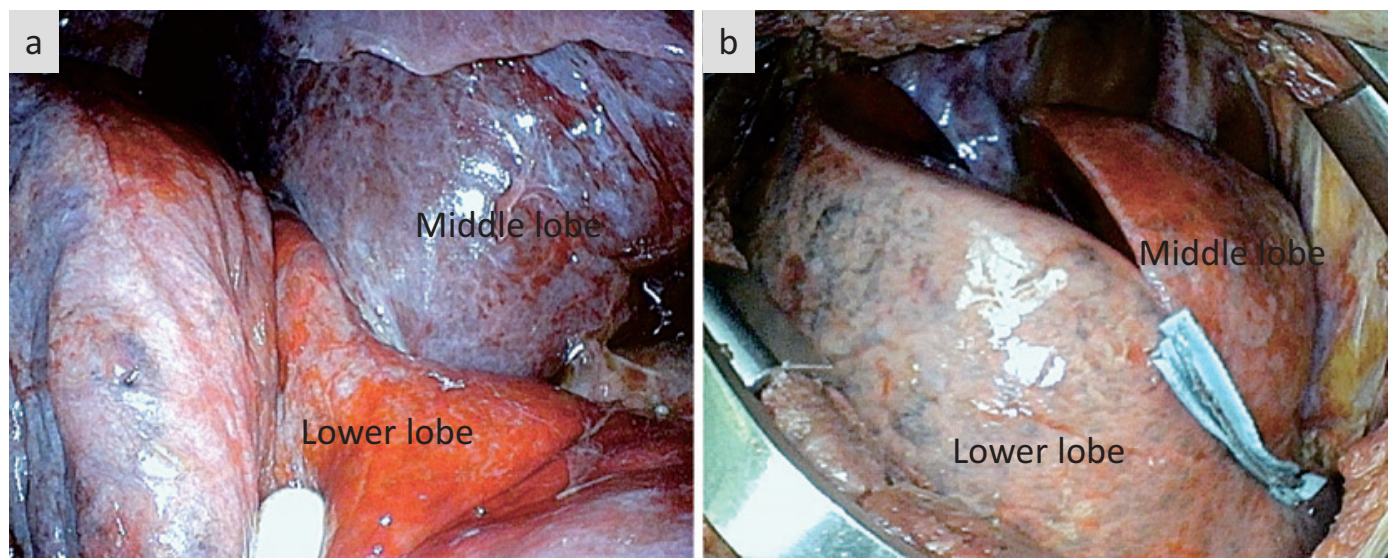

Fig. 3 (a) On postoperative day 3, emergent surgery was performed. An intraoperative image showed that the right upper lobe had rotated $90^{\circ}$ counterclockwise toward the hilum. (b) Detortion without resection of the middle lobe was performed. The middle lobe was fixed to the lower lobe using an automatic suture device. 
が観察可能であったため捻転の診断に至らなかった例も ある ${ }^{4)}$. 一方 CT 検査では, 無気肺や気管支・血管のねじ れや途絶所見などが診断の一助となることがある. 発熱, 血痰, 呼吸困難など特異的な症状が無くても, 急性発症 もしくは増悪傾向にある無気肺を認めた場合は本疾患を 積極的に疑うべきである. また, 決定的な診断方法は確 立していないため各検查の利点と限界を考慮し総合的な 判断が必要である.

治療についての第一選択は可及的早期の手術である. 捻転解除もしくは肺切除が行われているが, その治療選 択の指針は明らかになっていない. 開胸時に出血性肺壊 死が疑われる場合や肺静脈血栓が疑われる場合には, 肺 静脈切除を先行するべきで捻転解除を行ってはならな い. 本症例においては, 低肺機能であることと術前の症 状や術中所見で肺壊死を疑わせる所見が無かったことよ り捻転解除術を選択した. 造影 CT は血管走行, 血流の状 態, 肺壊死の有無を診断する上で必須であり, 撮影の上 で術式の判断を行う慎重さが必要であっだ. また, 捻転 解除をする際は，両側頸動脈の圧迫を行ってもよかった かもしれない.

捻転解除についての問題点は, 肺静脈血栓による脳塞 栓と虚血再還流に打ける chemical mediatorによる ARDS 発症があげられる. 中でも, 肺静脈血栓について 確立した検査法は無い. 発症から手術までの時間が短い 事が捻転解除の前提条件であるが, 発症後 16 時間と比較 的短時間に開胸手術を行ったにもかかわらず静脈内血栓 から脳塞栓を来した報告もある ${ }^{5,6)}$. そのため, 捻転解除 の golden time の設定は困難と推定される. 肺静脈血检 の有無については, 経食道エコーや 4D MRI などの応用 も検討すべき課題である. Dai らの検討において, 捻転解 除は肺切除と比較し予後に差は無かっだ7. 日常臨床にお いては, 呼吸機能が良好な症例では安全のため肺切除が 選択されやすいのではないだろうか.

今回は, 全身状態が安定しており気管支鏡検査におけ る所見にそしく，術中所見で肺壊死を認めなかったため 捻転解除を選択することができた，その要因として，不 完全な捻転により血管閉塞の程度が軽く無気肺主体の病 態であったことが推測される.

本症例では肺勒帯を切離したことと分葉が良好であっ たことが肺捻転症の要因であったと思われる ${ }^{8}$. 右肺上葉 切除症例に扔いて, 完全分葉や肺門リンパ節郭清により 細い気管支血管茎となった場合は, 今回行った自動縫合

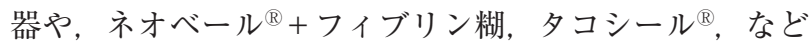
による捻転予防を考慮したい ${ }^{9,10)}$.

\section{結語}

右肺上葉切除後の中葉捻転症に対して, 幸いにも合併 症無く捻転解除を行うことができた，今後，どのような 症例に対して捻転解除を行うことができるかさらなる検 討が必要と考えられた。

\section{謝辞}

本例の英文要旨の作成においてご指導頂いた，鹿児島 大学呼吸器外科准教授, 上田和弘先生に深謝致します.

\section{利 益相反}

本論文において申告する利益相反はない.

\section{文献}

1. Cable DG, Deschamps C, Allen MS, Miller DL, Nichols FC, Trastek VF, et al. Lobar torsion after pulmonary resection: presentation and outcome. J Thorac Cardiovasc Surg 2001; 122: 1091-3.

2. Felson B. Lung torsion: radiographic findings in nine cases. Radiology 1987; 162: 631-8.

3. Banki F, Velmahos GC. Partial pulmonary torsion after thoracotomy without pulmonary resection. J Trauma 2005; 59: 478-81.

4. 大畑賀央, 宇佐美範恭, 谷口哲郎, 相馬孝博, 横井香平. 右上葉管状切除術後の中葉捻転の診断に対し造影 CT が 有用であった 1 例. 日呼外会誌 2009; 23: 866-70.

5. 井上博元, 井上宏司, 金淵一雄, 小川純一, 小出司郎策, 川田志明, 他. 左下葉切除後肺軸捻転を呈し, 開胸整復術 により脳梗塞を併発した 1 例. 胸部外科 1990; 43: 724-7.

6. Apostolakis E, Koletsis EN, Panagopoulos N, Prokakis C, Dougenis D. Fatal stroke after completion pneumonectomy for torsion of left upper lobe following left lower lobectomy. J Cardiothorac Surg 2006; 1: 25.

7. Dai J, Xie D, Wang H, He W, Zhou Y, Hernandez-Arenas LA, et al. Predictors of survival in lung torsion: A systematic review and pooled analysis. J Thorac Cardiovasc Surg 2016; 152: 737-45 e3.

8. 成田久仁夫, 岩波 洋, 日吉晴久, 立花正徳, 坪井栄孝. 上葉切除術後気管支変形予防に対する肺䩲带温存の検 
討. 気管支学 1997; 19: 206-10.

9. Uramoto H, Takenoyama M, Hanagiri T. Simple prophylactic fixation for lung torsion. Ann Thorac Surg 2010;

90: $2028-30$.
10. Fiorelli A, Scaramuzzi R, Costanzo S, Volpicelli A, Santini M. Interlobar fixation using TachoSil ${ }^{\circledR}$ : a novel technique. Transl Lung Cancer Res 2015; 4: 605-9.

\title{
Incomplete pulmonary middle lobe torsion after right upper lobectomy
}

\author{
Koki Maeda*1, Koichi Sakasegawa*2, Hiroo Nishijima*3 \\ Nobuhiro Imamura*1, Shoichiro Morizono ${ }^{* 1}$, Masami Sato ${ }^{* 1}$ \\ ${ }^{* 1}$ Department of General Thoracic Surgery, Graduate School of Medical and Dental Sciences, \\ Kagoshima University, Kagoshima, Japan \\ ${ }^{* 2}$ Department of General Thoracic Surgery, Kagoshima City Hospital, Kagoshima, Japan \\ ${ }^{* 3}$ Department of General Thoracic Surgery, Kagoshima Kouseiren Hospital, Kagoshima, Japan
}

Background. Torsion of the remaining lobe after a lobectomy is a rare complication which requires prompt surgical intervention. The twisted lobe is repositioned or resected on a case-by-case basis. Case. A 63-year-old man with COPD underwent right upper lobectomy and lymph node dissection for T2aN0M0 lung cancer. The patient had a compromised pulmonary function with a forced expiratory volume in 1 second of $1.32 \mathrm{~L}$ and a diffusion capacity of 30.9\%. Emergency rethoracotomy was performed due to incomplete middle lobe torsion that was suggested by computed tomography. The middle lobe was repositioned to preserve the lung function. The middle lobe recovered successfully and the subsequent clinical course was uneventful. Conclusion. Repositioning of a twisted lobe can be performed in selected patients after careful assessment. 